www.jmscr.igmpublication.org

Impact Factor 5.244

Index Copernicus Value: 83.27

ISSN (e)-2347-176x ISSN (p) 2455-0450

crossref DOI: http://dx.doi.org/10.18535/jmscr/v4i8.83

\author{
Journal Of Medical Science And Clinical Research \\ IGM Publication \\ An official Publication of IGM Publication
}

\title{
A Study on Rare Cases and Bacterial Infections in Children
}

\author{
Author \\ Payala Vijayalakshmi \\ Department of Microbiology, GITAM Institute of Medical Sciences and Research, GITAM University \\ Website: www.gitam.edu, Phone: + 918912790202 / 2840222, Fax: + 918912790399 \\ Corresponding Author \\ Dr P.Vijayalakshmi \\ Department of Microbiology, GITAM Institute of Medical Sciences and Research, \\ GITAM UNIVERSITY, Visakhapatnam-530 045, Andhra Pradesh, India \\ Email: bavisettyvijayalakshmi2@gmail.com,Mob: + 91-7396814333
}

\begin{abstract}
The present was a short-term study and conducted for a period of five months in order to study the incident rate of bacterial infections that occur commonly and rarely in children. A total of 50 clinical samples like blood, urine, pus, stool, nasal secretions, sputum etc. were collected from children suffering with various types of diseases like urinary tract, gastro intestinal, skin, ear, upper and lower respiratory tract infections caused by bacteria. Positive growth was identified in 31 samples and the bacterial infections represented by Streptococcus pneumoniae (2 samples), Methicillin resistant Staphylococcus aureus (MRSA) (5), Staphylococcus aureus (3), Escherichia coli (3), Klebsiella species (2), Pseudomonas aeruginosa (5), Citrobacter species (1), Enterococcus species (2), Coagulase negative staphylococci (5), Enterobacter species (1), Methicillin sensitive coagulase negative Staphylococcus aureus (2). Staphylococcus aureus was found to be the major pathogen isolated from the majority of clinical samples. The organism Staphylococcus aureus was also isolated from 5 years old boy suffering with Beta thalassemia Major and diagnosed with severe respiratory tract infections characterized by fever, cold, cough, and bronchiolitis. The antibiotic susceptibility pattern of the organisms was studied using Kirby-Bauer method.
\end{abstract}

Key words: Infections, Microorganisms, Antibiotic sensitivity, Beta thalassemia.

\section{INTRODUCTION}

In the present days the children were continuously posed to several types of microbial infections. This may be due to poor sanitary conditions, environmental pollution problems, eating unhealthy foods, malnutrition, prolonged illness, sedentary life style etc. leads to decrease in the immune resistant power. The commonest respiratory infections are localized in the oropharynx, nasopharynx and nasal cavity causing sore throat, nasal discharge, and often fever but the throat pathogens may also spread to infect the larynx, causing hoarseness; the middle ear causing otitis media with earache; a paranasal sinus, causing sinusitis with pain in the face or head; and the eye causing conjunctivitis or keratitis. The most common bacterial pathogens causes RTI are Pneumococcus, Haemophilusinfluenzae, Staphylococcus aureus and Streptococcus pyogenes ${ }^{[1]}$. The most common lower respiratory tract infections include acute tracheo bronchitis, acute exacerbations of chronic bronchitis and the 
pneumonias. In majority of cases, primary infection is caused by a virus but the secondary bacterial infections are caused by bacterial pathogens from the nasopharynx most commonly pneumococcus or Haemophilusinfluenzae, Staphylococcus aureus, Pseudomonas aeruginosa etc. ${ }^{[2]}$.Lung infections are commonly associated with bacteremia and it may be possible to culture from the blood a delicate pathogen whose growth is suppressed in the cultures of sputum contaminated with the salivary organisms. Acute otitis media is usually caused by Mycoplasma Pneumoniae, Pneumococcus, Moraxella catarrhalis, Haemophilusinfluenzae and Streptococcus pyogenes. Antibiotic therapy is urgently required to prevent a possible bacterial infection damaging the hearing mechanism and amoxicillin or erythromycin may be used when the causal organism is unknown ${ }^{[3]}$. Chronic inflammation of the skin of the external meatus with irritation and discharge may be caused by bacteria particularly Pseudomonas aeruginosa, Staphylococcus aureus, coliform bacteria etc. Infection of soft tissues is generally associated with the production of pus and the bacteria involved are said to be pyogenic. Staphylococcus aureus was isolated from pustules, boils, carbuncles, stitch abscesses and wound infections ${ }^{[4]}$. The commonest pyogenic bacteria Staphylococcus aureus, Streptococcus pyogenes, Pneumococcus, E.coli, Proteus, Pseudomonas aeruginosa etc. cause wound infections. For gastrointestinal infections the common specimen examined was faeces from patient with diarrhea, with or without abdominal pain or vomiting. The commonest infectious causes of diarrhoea in children over 2-3 years age are infections with Campylobacter Species, Enterobacteriaceae members, Clostridium perfringens, Vibrio parahaemolyticus, Bacillus cereus etc. ${ }^{[5]}$. In urinary tract infections the most common symptoms are urgency and frequency of micturition, with associated discomfort or pain. The commonest condition is cystitis due to infection of the bladder with uropathogenic bacterium, which most frequently is E.coli but sometimes

Staphylococcus saprophyticus,
Klebsiella, Proteus, Pseudomonas aeruginosa, Enterococcus. Mid-stream urine is collected from bacteriuria patient ${ }^{[6]}$. Beta thalassaemia syndromes are the blood disorders recognized by reduced or absent beta globin chain synthesis, leads to reduced haemoglobin in red blood cells, decreased RBC production and anaemia. The infant who are affected with thalassaemia major become progressively pale. The affected infant may got diarrhoea, irritability, fever, spleen and liver enlargement, growth retardation, pallor, jaundice, poor musculature, leg ulcers, hepato splenomegaly etc. The regular blood transfusions by maintaining haemoglobin levels 9.5 to $10.5 \mathrm{~g} / \mathrm{dl}$ cause the normal growth development till 10-12 years. However iron overload is the major problem in transfused patients leads to growth retardation and delayed sexual maturation. Iron chelation therapy help in reducing the complications in affected children ${ }^{[7]}$. Chung et al. isolated Klebsiella from transfusion dependent thalassaemia patient. Nonetheless, limited data are available with regard to the incidence of infection and spectrum of clinical presentation ${ }^{[8]}$. The incidence of infections among patients with thalassaemia and the role of risk factors for infection are uncertain ${ }^{[9]}$. Staphylococcus aureus was the major pathogen mainly related to infection, associated with iron chelation therapy. Many studies have showed that infection is common in thalassaemia patients and caused by Klebsiella pneumoniae, E.coli, Streptococcus pneumoniae, Staphylococcus aureus, Salmonella typhietc. [8],[10],[11],[12],[13]. The objective of the present study was to determine the rate and spectrum of infections occur among the children.

\section{MATERIALS AND METHODS}

In the present study 50 clinical samples namely Blood, Pus, Sputum, Stool, Nasal secretions, Throat swab, and Ear swab for bacteriological investigation were collected in sterile containers. Among them one sample was collected from 5 years old boy diagnosed with acute upper respiratory tract infection and suffered with Beta thalassaemia major characterized by severe spleno 
hepatomegaly, haemolyticanaemia. The haemoglobin levels were $4 \mathrm{~g} / \mathrm{dl}$ and the CRP levels were $145 \mathrm{mg} / \mathrm{l}$ and considered positive. Haemoglobin variant analysis is suggestive of a diagnosis homozygous Beta thalassaemia. The boy was detected with Thalassaemia at the age of 9 months. However blood intended primarily for blood culture was inoculated into a blood culture bottle. Swabs were used for taking specimens of exudate from the throat, nostril, skin, wound and other lesions. For urine samples the examinations made were the microscopy examination of a wet film to determine whether polymorphs or pus cells were present in numbers indicative of urinary tract infection. The clinical samples were now inoculated into a suitable enrichment, differential and selective media like Mannitol salt agar, Mac Conkey agar, Blood agar, EMB agar, Choclate agar, Loeffler's serum slope, TCBS agar, XLD agar, Deoxycholate citrate agar. The plates were incubated for $24 \mathrm{~h}$ and later identified for the presence of bacterial growth. A Gram staining was performed to identify the morphological features of the isolates and biochemical tests like Catalase, Coagulase, IMViC, Urease test, Oxidase test, O/F test, Nitrate reduction test, TSI agar test, CAMP test, PYRase test, Bile solubility test, Sugar fermentation tests etc. were used for the organism confirmation. Mueller Hinton agar was used to perform Antibiotic susceptibility pattern of microorganisms using Kirby Bauer method. Standard Hi-grade antibiotics (Hi Media Laboratories) were used for the test ${ }^{[14]}$.

\section{RESULTS AND DISCUSSION}

Among 50 pediatric samples screened for the presence of bacterial growth 31 samples show positive. The isolated organisms were Streptococcus pneumoniae, Methicillin resistant Staphylococcus aureus, Pseudomonas aeruginosa, Staphylococcus aureus, Klebsiella pneumoniae, Citrobacter, Escherichia coli, Enterococcus, Enterobacter, Coagulase negative Staphylococci, Methicillin sensitive coagulase negative Staphylococcus aureus (Table 1). Alteret al. reported that bacterial pneumonia was common in younger children and accounts for $13 \%$ of all infection illnesses in infants younger than 2 years of age ${ }^{[15]}$. The organisms most commonly cause were E.coli, Streptococcus pneumoniae, Klebsiella pneumoniae. In the present study four pneumonia cases were identified and the organisms Streptococcus pneumoniae and Klebsiella pneumoniae were highly susceptible to Linezolid, Ciprofloxacin, Tetracycline and Gentamycin, Amikacin, Ertapenem, Methicillin, Ciprofloxacin (Table 2). However Staphylococcus aureus (coagulase positive, MRSA and Coagulase negative) were the predominant organisms isolated. The organism was also isolated from the Beta thalassaemia patient suffered with severe respiratory tract infection. The results were similar while comparing with the previous studies $[8],[10],[11],[12],[13]$. The organism was sensitive to antibiotics like Cefuroxime, Tetracycline, Linezolid, Vancomycin, Ceftriaxone and Gentamycin (Table 2). Methicillin resistant Staphylococcus aureus was identified in 5 cases of skin infections like Carbuncles, furuncles and Impetigo. MRSA was the common pathogen isolated from the soft tissues ${ }^{[15],[16]}$.The organism Pseudomonas aeruginosa was screened from children suffering with wound infections, skin infections and respiratory tract infections. The organism was highly sensitive to Ceftazidime, Ciprofloxacin, and Amikacin. Algun et al. showed that 136 strains of Pseudomonas exhibit high and medium susceptibility to antibiotic ciprofloxacin [17]. Urinary tract infection seen in $5 \%$ of febrile infants and $2 \%$ of febrile children more than 5 years of age and reoccurs again in 50\% of schoolaged girls within 6-12 years. Male children were more prone to UTI when compared to females ${ }^{[18]}$. Escherichia coli, Proteus are seen in more number of cases. In the present study along with E.coli the other organismCitrobacterwas cultured from urine. The organism showed high sensitivity to Ceftriaxone, Ampicillin/Salbactum (Table 2) (Figure 1). By examining the stool cultures, three organism were identified which cause gastrointestinal infections were Enterococcus, 
Enterobacter and E.coli. $75 \%$ of children experience at least one episode of otitis media within 3 years of age. The causal organisms were Streptococcus pyogenes and Staphylococcus sensitive to antibiotic like Amoxicillin, Cefuroxime, Ceftriaxone, Cefpodoxime etc. ${ }^{[18]}$. The current findings showed that Methicillin sensitive Staphylococcus aureus and coagulase negative Staphylococciwere isolated from ear swabs. The coagulase negative Staphylococcihave become the commonest pathogens in neonatal intensive care units and present special problems both of diagnosis and management.

As the bacterial infections in children increases the mortality and morbidity rates in the present scenario might be due to conditions like malnutrition, immune deficiency states, prolonged illness etc. Hence to prevent or reduce the infection rate in children the first key step is the responsibility of the parents to maintain good hygienic conditions of the children, taking appropriate antibiotics, nourished with enriched foods contains high amounts of proteins, vitamins and minerals. This causes the boosting of immune resistant power and the children should be under the continuous supervision of specific physician.

Table 1: Percentage of organism Isolated in pediatric Infections

\begin{tabular}{|l|l|l|l|}
\hline S.No & Name of the organism & $\begin{array}{l}\text { Positive } \\
\text { samples }\end{array}$ & Percentage \\
\hline 01 & Streptococcus pneumoniae & 2 & $4 \%$ \\
\hline 02 & $\begin{array}{l}\text { Methicillin resistant } \\
\text { Staphylococcus aureus }\end{array}$ & 5 & $10 \%$ \\
\hline 03 & Pseudomonas aeruginosa & 5 & $10 \%$ \\
\hline 04 & Staphylococcus aureus & 3 & $6 \%$ \\
\hline 05 & Klebsiella pneumoniae & 2 & $4 \%$ \\
\hline 06 & Citrobacter & 1 & $2 \%$ \\
\hline 07 & Escherichia coli & 3 & $6 \%$ \\
\hline 08 & Enterococcus & 2 & $4 \%$ \\
\hline 09 & Enterobacter & 1 & $2 \%$ \\
\hline 10 & $\begin{array}{l}\text { Coagulase } \\
\text { Staphylococci }\end{array}$ & 5 & $10 \%$ \\
\hline 11 & $\begin{array}{l}\text { Methicillin sensitive coagulase } \\
\text { negative Staphylococcus aureus }\end{array}$ & 2 & $4 \%$ \\
\hline
\end{tabular}

Table 2: Antibiotic Sensitivity Pattern of the Isolates

\begin{tabular}{|c|c|c|}
\hline Name of the organism & $\begin{array}{l}\text { Sensitive } \\
\text { antibiotics }\end{array}$ & Resistant to antibiotics \\
\hline Streptococcus pneumoniae & $\begin{array}{lll}\text { LZD, } & \text { CIP, } & \text { TET, } \\
\text { GEN } & \end{array}$ & CXM, AMP, LOM \\
\hline $\begin{array}{l}\text { Methicillin } \quad \text { resistant } \\
\text { Staphylococcus aureus }\end{array}$ & $\begin{array}{l}\text { CXM, GEN, } \\
\text { ERY, CIP, } \\
\text { VAN, LZD }\end{array}$ & PEN, COT, TET \\
\hline Pseudomonas aeruginosa & $\begin{array}{l}\text { CAZ, PIP, ETP, } \\
\text { GEN, CIP, AMK }\end{array}$ & $\begin{array}{l}\text { AMP, TET, COT, A/S, } \\
\text { CXM }\end{array}$ \\
\hline Staphylococcus aureus & $\begin{array}{lll}\text { CXM, } & \text { TET, } & \text { LZD, } \\
\text { VAN, } & \text { CTR, } & \text { GEN, } \\
\text { A/S } & & \\
\end{array}$ & CIP, PEN, ERY \\
\hline Klebsiella pneumoniae & $\begin{array}{l}\text { AMK, ETP, MET, } \\
\text { CIP }\end{array}$ & $\begin{array}{l}\text { AMX, CXM, PIP, CPM, } \\
\text { CAZ, CTR, CLA, COT, } \\
\text { AMP }\end{array}$ \\
\hline Citrobacter & $\begin{array}{l}\text { CTR, A/S, IPM, } \\
\text { CAZ, CPM, GEN, } \\
\text { TET, CIP, CAC }\end{array}$ & $\begin{array}{l}\text { PIP, LOM, AMX, COT, } \\
\text { NIT, CXM, AMK, AMP, } \\
\text { NOR }\end{array}$ \\
\hline Escherichia Coli & $\begin{array}{l}\text { CAC, NIT, } \\
\text { AMK, GEN }\end{array}$ & $\begin{array}{l}\text { CAZ, ETP, TET, COT, } \\
\text { CXM, CPM, AMP, CIP, } \\
\text { PIP, LOM, NOR, CTR, } \\
\text { AMX }\end{array}$ \\
\hline Enterococcus & $\begin{array}{lll}\text { CPM, TET, } & \text { GEN, } \\
\text { CTR, VAN, } & \text { CTX, } \\
\text { LZD, ERY } & \end{array}$ & AMP, CIP, PEN \\
\hline Enterobacter & $\begin{array}{l}\text { NOR, GEN, IPM, } \\
\text { TET, A/S }\end{array}$ & $\begin{array}{l}\text { AMP, CAC, NIT, CAZ, } \\
\text { CPM, CIP, CTR }\end{array}$ \\
\hline $\begin{array}{ll}\text { Coagulase } & \text { negative } \\
\text { Staphylococci } & \\
\end{array}$ & $\begin{array}{l}\text { A/S, TET, LZD, CIP, } \\
\text { VAN }\end{array}$ & $\begin{array}{l}\text { PEN, ERY, COT, CXM, } \\
\text { CTR, GEN, NOR }\end{array}$ \\
\hline $\begin{array}{lr}\text { Methicillin } & \text { sensitive } \\
\text { coagulase } & \text { negative } \\
\text { Staphylococcus } & \text { aureus }\end{array}$ & $\begin{array}{llr}\text { PEN, } & \text { MET, } & \text { A/S, } \\
\text { CXM, CTR, } & \text { CIP, } \\
\text { TET, GEN, VAN, } \\
\text { LZD }\end{array}$ & ERY \\
\hline
\end{tabular}

Drugs evaluated: PEN: Penicillin, CIP: Ciprofloxacin, LZD: Linezolid, A/S: Ampicillin/Salbactum, TET: Tetracycline, ERY: Erythromycin, GEN: Gentamycin, AMK: Amikacin, CXM: Cefuroxime, AMP: Ampicillin, LOM: Lomefloxacin, CTR: Ceftriaxone, VAN: Vancomycin, CAZ: Ceftazidime, PIP: Pipercillin, ETP: Ertapenem, Met: Methicillin, AMX: Amoxicillin, CLA: Clavulanic acid, COT: Cotrimaxazole, IPM: Imipenem, NIT: Nitrofurantoin, CXM: Cefuroxime, NOR: Norfloxacin, CTX: Cefotaxime, CPM: Cefpiramide, CEC: Cefaclor, CAC: Ceftazidime/ Clavulanic acid.

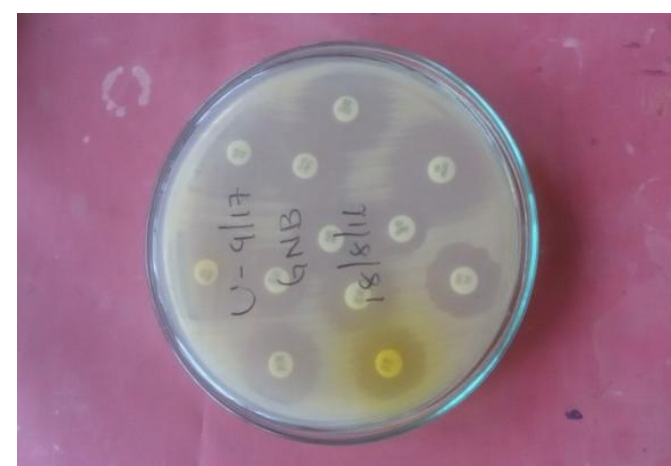

Fig 1: Antibiotic sensitivity of Citrobacter 


\section{ACKNOWLEDGEMENT}

The author would like to thank all the faculty members of Dept. of microbiology, Gitam institute of medical sciences and research, Gitam University and Andhra medical college, Visakhapatnam. My sincere gratitude to Dr. J.V.V.S.N Murthy Ex-principal of Dr.V.S. Krishna Govt. College and Dr.D.Sarvamangla, Associate Prof., Gitam University for giving a valuable suggestions. The work was not supported by any grants and funds.

\section{REFERENCES}

1. P.V. Dasaraju and C. Liu, Infections of the respiratory system, Medical microbiology, $4^{\text {th }}$ ed., S Baron, University of Texas Medical branch at Galveston: 1996.

2. B.A. Rawlings, M.S.P.H. Thomas Higgins and K. Joseph Han, "Bacterial pathogens in the nasopharynx, nasal cavity, Osteomeatal complex during wellness and viral infection," Am. J. Rhinol. Allergy., Vol. 27, pp. 39-42, 2013.

3. T. Chonmaitree, "Acute Otitis media is not a pure bacterial disease", Clinical infection Dis., Vol. 43, pp. 1423-1425, 2006.

4. P. Bernard, "Management of common bacterial infections of the skin", Curr. Opin. Infect. Dis, Vol21, pp 122-128, 2008

5. M. Stephen Murphy, "Management of bloody diarrhoea in children in primary care", BMJ,Vol. 336, pp 1010-1015, 2008.

6. SurinderKumar, Text book of Microbiology, $1^{\text {st }}$ ed., Jaypee Brothers Medical Publishers Pvt. Ltd., New Delhi: 2012.

7. R. Galanello and R. Origa, "Betathalassemia", Orphanet J. Rare Diseases., Vol 5, pp. 1-15, 2010.

8. B.H.Y. Chung, S.Y. Ha, G.C.F. Chan, A. Chiang, T.L. Lee, H.K. Ho, C.Y. Lee, C.W. Luk and Y.L. Lau, "Klebsiella Infection in patients with Thalassemia", CID., Vol 36, pp. 575-579, 2003.

9. G. Rahav, V.Volach, M. Shapiro, D.Rund, E.A. Rachmilewitz and A. Goldfarb,
"Severe infections in thalassaemic patients: prevalence and predisposing factors", British J of Haematology., Vol 133, pp.667-674, 2006.

10. W. Wanachiwanawin, "Infections in $E / \beta$ thalassaemia", J. Pediatric Hematology, Vol 22, pp.581-587, 2000.

11. C.K. Li, M.M. Shing, K.W. Chik, V. Lee and P.M Yuen, "Klebsiella pneumoniae meningitis in thalassemia major patients", Pediatric Hematology and Oncology., Vol 18, pp. 229-232, 2001.

12. S.C. Wang, K.H. Lin, J.P. Chern, M.Y. Lu, S.T.Jou, D.T. Lin and K.S. Lin, "Severe bacterial infection in transfusion dependent patients with thalassaemia major", Clinical infectious diseases., Vol 37, pp. 984-988, 2003.

13. E. Wiener, "Impaired phagocyte antibacterial effector functions in $\beta$-thalassaemia a likely factor in the increased susceptibility to bacterial infections", Hematology., Vol 8, pp. 35-40, 2003.

14. Mackie and McCartney,Practical medical microbiology, 14th ed., Churchill Livingstone, An imprint of Elsevier publications: 1996.

15. S.J.Alter, N.K. Vidwan, P.O. Sobande, A. Omoloja, J.S. Bennett, "Common childhood bacterial infections", Curr. Probl. Pediatr. Adolesc. Health care., Vol 41, pp. 256-283, 2011.

16. N. Zetola, J.S. Francis, EL. Nuermberger, "Community acquired MRSA: an emergency threat", Lanat infect. Dis., Vol 5, pp. 275-286, 2005.

17. U. Algun, A. Arisoy, T. Gunduz and B. Ozbakkaloglu, "The resistance of Pseudomonas aeruginosa strains to Fluoroquinolone group of antibiotics", Indian J Med Microbiol., Vol 22, pp.112114, 2004.

18. J.F.Jones and V.A.Fulginiti, "Recurrent bacterial infections in children", Pediatrics in Review., Vol 1, pp. 99-108, 1979. 